\title{
PENGARUH KOMPOSISI DAN UKURAN SERBUK KULIT KERANG DARAH (ANADORA GRANOSA) TERHADAP KEKUATAN TARIK DAN KEKUATAN BENTUR DARI KOMPOSIT EPOKSI-PS/SERBUK KULIT KERANG DARAH
}

\author{
Addriyanus, Tommy, Halimatuddahliana \\ Departemen Teknik Kimia, Fakultas Teknik, Universitas Sumatera Utara, \\ Jl. Almamater Kampus USU Medan 20155 Indonesia \\ Email: addriyanus@ hotmail.com
}

\begin{abstract}
Abstrak
Penelitian ini bertujuan untuk mengetahui pengaruh komposisi dan ukuran serbuk kulit kerang darah terhadap nilai kekuatan tarik dan kekuatan bentur dari komposit epoksi-PS/serbuk kulit kerang darah (SKKD). Bahan yang digunakan dalam penelitian ini adalah resin epoksi sebagai matriks, polyaminoamide sebagai hardener, serbuk kulit kerang darah sebagai pengisi, polistirena sebagai toughening agent dan kloroform sebagai pelarut. Komposisi pengisi divariasikan dari 10$50 \%$, sedangkan ukuran pengisi divariasikan dari 50-260 mesh. Komposit dicetak dengan menggunakan metode compression moulding, kemudian dilakukan pengujian nilai kekuatan tarik dan kekuatan bentur dari komposit. Hasil yang diperoleh yaitu penambahan SKKD berhasil meningkatkan nilai kekuatan tarik dan kekuatan bentur dari komposit. Pada komposit dengan komposisi pengisi 30\% dan ukuran 200 mesh dihasilkan nilai kekuatan tarik maksimum yaitu 5,50 MPa dan pada penambahan SKKD dengan komposisi pengisi 30\% dan ukuran 170 mesh dihasilkan nilai kekuatan bentur maksimum yaitu $30044,3 \mathrm{~J} / \mathrm{m}^{2}$.
\end{abstract}

Kata kunci: kekuatan tarik, kekuatan bentur, komposit, resin epoksi, serbuk kulit kerang darah

\begin{abstract}
This study was aimed to investigate the effect of filler content and particle size of cockle-shell powder in tensile strength and impact strength of epoxy-PS composite. Epoxy resin was used as matrix, polyaminoamide as hardener, cockle-shell powder as reinforcement, polystyrene as toughening agent and chloroform as solvent. Filler content was varied from 10-50\% and the macro particle was varied from 50-260 mesh. The composite was prepared by using compression moulding, then tensile test and flexural test were done. The results showed that addition of cockleshell powder improved both tensile strength and impact strength of the composite. Addition of $30 \%$ (wt) reinforcement with 200 mesh particle size had given maximum tensile strength of 5,50 MPa and maximum impact strength of $30044,3 \mathrm{~J} / \mathrm{m}^{2}$.
\end{abstract}

Keywords: tensile strength, flexural strength, composite, epoxy resin, cockle-shell powder

\section{Pendahuluan}

Polimer epoksi adalah kelas polimer termoset yang banyak digunakan saat ini. Adapun kelebihan dari polimer epoksi adalah ketahanannya terhadap suhu, dan cuaca, selain itu polimer epoksi juga bersifat isolator dan juga pemrosesannya mudah [3]. Pemanfaatan polimer epoksi banyak sebagai pelapis, perekat, dan matrik pada material komposit dan telah banyak digunakan dalam banyak aplikasi seperti otomotif, aerospace, perkapalan dan sebagainya [18]. Namun polimer epoksi bukan polimer yang kuat karena strukturnya yang rapuh, mudah retak dan memiliki ketahanan yang rendah terhadap pukulan atau tekanan [7].

Untuk meningkatkan kekuatan dari polimer epoksi ini telah banyak dilakukan penelitian, diantaranya dengan penambahan pengisi alami. Adapun penelitian-penelitian sebelumnya menggunakan bahan-bahan alami seperti nanas [19], sisal [13], kulit kelapa [6], rami [23], sekam padi [1], bambu [2], dan serbuk kayu [20].

Pada penelitian ini, sampel yang digunakan adalah kulit kerang darah (Anadora granosa) yang mengandung $\mathrm{CaO}$ dan $\mathrm{MgO}$ yang relatif tinggi yaitu masing-masing $66,70 \%$ dan $22,28 \%$ [11], dengan kandungan 
tersebut, kulit kerang memiliki sifat yang relatif sangat kuat.

Kerang laut merupakan salah satu hasil komoditi laut favorit, namun sebagian besar pemanfaatannya masih terbatas pada daging kerang untuk dikonsumsi. Hasil panen kerang per hektar untuk tiap tahunnya bisa mencapai 200-300 ton kerang utuh yang menghasilkan daging kerang 60-100 ton [22]. Sisanya yaitu kulit kerang hanya dimanfaatkan sebagai kerajinan tangan atau seni dekoratif, juga sebagai campuran makanan ternak guna memenuhi kadar kalsium [17], oleh sebab itu, keberadaan limbah kulit kerang semakin lama semakin banyak dan menganggu. Jika limbah dibuang terus menerus tanpa adanya pengolahan yang tepat dapat menimbulkan gangguan keseimbangan, dengan demikian menyebabkan lingkungan tidak berfungsi seperti semula dalam arti kesehatan, kesejahteraan, dan keselamatan hayati [15].

Dalam penelitian ini akan dikaji sifat mekanik komposit yang meliputi uji tarik dan uji bentur.

\section{Teori}

Pengertian komposit menurut Campbell, yaitu kombinasi dari dua atau lebih bahan yang menghasilkan sifat yang lebih baik daripada sifat komponen-komponen yang digunakan itu. Berbeda dengan paduan logam, pada bahan komposit masing-masing bahan penyusun tetap mempertahankan fisik, dan sifat mekaniknya [5].

Menurut Kaw, komposit adalah bahan struktural yang terdiri dari dua atau lebih unsur gabungan yang digabungkan pada tingkat makroskopik dan tidak larut dalam satu sama lain. Satu konstituen disebut fase pengisi (reinforcements) dan satu fasa lagi dimana pengisi tertanam disebut matriks [14].

Matriks yang digunakan pada penelitian ini adalah resin epoksi. Epoksi adalah plastik thermoset yang paling umum digunakan sebagai matriks pada komposit karena epoksi memiliki sifat adhesi yang baik untuk bahan lainnya, memilik ketahanan yang bagus terhadap lingkungan dan zat kimia, serta bagus sebagai bahan insulasi [16]. Selain itu epoksi juga tidak bersifat volatil dan tingkat penyusutannya juga rendah, serta gampang untuk diolah [8].

Pada percobaan ini digunakan pengisi berbentuk serbuk yaitu serbuk kulit kerang darah (Anadora granosa). Anadara granosa hidup dengan cara membenamkan diri di pantai-pantai dan terdapat di pantai laut pada substrat lumpur berpasir dengan kedalaman 10 m sampai $30 \mathrm{~m}$ [24]. Anadora granosa mempunyai ciri khas yaitu ditutupi oleh dua keping cangkang (valve) yang dapat dibuka dan ditutup karena terdapat sebuah persendian berupa engsel elastis yang merupakan penghubung kedua valve tersebut [21].

Komposit yang telah dibuat akan diuji sifat- sifat mekanik yaitu uji tarik dan uji bentur. Kekuatan tarik (tensile strength) suatu bahan ditetapkan dengan membagi gaya maksimum dengan luas penampang mulamula [10]. Pengujian bentur dilakukan untuk mengetahui karakteristik patah dari bahan [4].

\section{Metodologi \\ Bahan}

Bahan baku yang digunakan sebagai matriks adalah resin epoksi yang merupakan campuran antara resin dengan pengeras (polyaminoamide). Polistirena (PS) digunakan sebagai toughening agenta, dan kloroform digunakan sebagai pelarut polistirena. Sementara pengisi yang digunakan adalah serbuk kulit kerang darah (Anadora granosa).

\section{Penyediaan Pengisi Komposit}

Kulit kerang dicuci dengan menggunakan air dan dikeringkan dengan cara dijemur menggunakan cahaya matahari. Kulit kerang kemudian digiling dengan ball mill sehingga kerang tersebut menjadi serbuk selama 8 jam. Dilakukan pengayakan dengan ayakan 50, 80, 110, 140, 170 dan 200 mesh.

\section{Penyediaan Matriks Komposit}

Polistirena (PS) dilarutkan dalam kloroform dengan perbandingan 1:4 (b/b). Kemudian resin epoksi dicampurkan dengan hardener poliaminoamide dengan rasio 1:1 (b/b). Epoksi resin dan polistirena yang sudah disiapkan dimasukkan ke dalam wadah dengan perbandingan $90 \%$ epoksi dan $10 \%$ PS. Campuran diaduk hingga merata.

\section{Proses Pembuatan Komposit}

Dilakukan percampuran antara matriks dan pengisi dengan komposisi pengisi serbuk kulit kerang darah sebesar 10\%, 20\%, 30\%, $40 \%$ dan $50 \%$ (\%wt) dan variasi ukuran serbuk kulit kerang darah sebesar 50, 80, 110, 140 dan 170 mesh ke dalam wadah. Alas cetakan besi terlebih dahulu diberikan bahan pelicin seperti gliserin agar resin tidak melekat pada cetakan, kemudian dituangkan campuran bahan ke dalam cetakan besi yang telah dibentuk sesuai standar uji kekuatan bentur dan standar uji kekuatan tarik. Ratakan permukaan campuran pada cetakan. Campuran 
komposit di-press dengan menggunakan alat Compresssion Molding selama 10 menit kemudian komposit dibiarkan selama 24 jam hingga mengering. Komposit yang sudah kering dilepas dari cetakan kemudian dihaluskan bagian-bagian permukaannya dengan alat kikir dan amplas. Dilakukan pengujian terhadap komposit.

Pengujian kekuatan tarik komposit menggunakan standar ASTM D-638 dengan mesin uji universal GOTECH AL-7000M. Panjang alat ukur ditetapkan $72 \mathrm{~mm}$ dengan kecepatan $50 \mathrm{~mm} /$ menit Mesin dihidupkan dan spesimen akan tertarik ke atas spesimen diamati sampai putus, dicatat tegangan maksimum dan regangannya.

Pengujian kekuatan bentur dilakukan dengan mesin Impact Tester Gotech dengan standar ASTM D4812. Sampel dijepit kemudian dihantam dengan pendulum hingga patah, kemudian dicatat energi yang diserap sampel sebelum patah.

\section{Hasil}

\section{Kekuatan Tarik (Tensile Strength)}

Gambar 1 menunjukkan pengaruh ukuran partikel dan komposisi serbuk kulit kerang darah terhadap kekuatan tarik (tensile strength) komposit epoksi-PS/SKKD

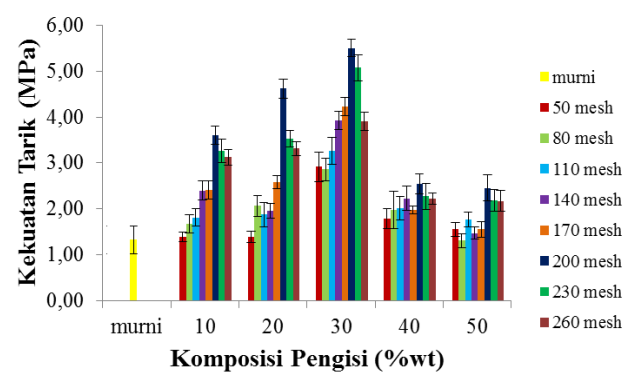

Gambar 1. Pengaruh Komposisi Dan Ukuran SKKD Terhadap Kekuatan Tarik Komposit Epoksi-PS/SKKD

Pengujian kekuatan tarik dilakukan untuk mengetahui untuk seberapa besar gaya yang diperlukan untuk menarik bahan hingga patah. Semakin besar nilai kekuatan tarik suatu bahan berarti dibutuhkan gaya yang lebih besar untuk menarik bahan.

Pada gambar 1, dapat dilihat bahwa dengan menambahkan pengisi serbuk kulit kerang darah, nilai kekuatan tarik komposit epoksi-PS/SKKD lebih tinggi dibandingkan dengan epoksi-PS murni, hal ini menunjukkan bahwa proses pembasahan pengisi oleh matriks cukup bagus, sehingga terjadi interaksi fisik yang bagus antara pengisi dengan matriks.
Pada gambar 1 dapat dilihat bahwa nilai kekuatan tarik dari komposit epoksi-PS/SKKD untuk ukuran partikel yang sama, cenderung mengalami peningkatan seiring dengan penambahan komposisi pengisi sampai $30 \%$.

Pada komposisi 30\%, nilai kekuatan tarik mencapai 5,50 $\mathrm{MPa}$ dan kemudian nilai kekuatan tarik komposit mulai menurun pada komposisi pengisi sebesar $40 \%$ dan $50 \%$, seperti pada komposisi $50 \%$ dengan ukuran 80 mesh, nilai kekuatan tarik menurun hingga mencapai 1,31 MPa, hal ini disebabkan karena ketika komposisi pengisi telah melewati suatu titik optimum, partikel pengisi akan mengalami aglomerasi membentuk suatu partikel yang lebih besar dan tidak merata sehingga menurunkan kekuatan tarik komposit [12].

Kekuatan tarik komposit epoksiPS/SKKD juga cenderung mengalami peningkatan seiring dengan menurunnya ukuran partikel. Dari gambar di atas dapat dilihat bahwa nilai kekuatan tarik yang terbesar terdapat pada komposit dengan ukuran pengisi 200 mesh pada komposisi pengisi $10 \%$ sampai $30 \%$, hingga mencapai nilai 5,50 $\mathrm{MPa}$ pada ukuran 200 mesh dan komposisi 30\%. Semakin kecil ukuran partikel akan lebih memudahkan penyebaran partikel pengisi sehingga interaksi fisik antara pengisi dan matriks menjadi lebih bagus dan mengakibatkan efek penguatan yang diberikan oleh pengisi dapat lebih merata sehingga dapat meningkatkan sifat kekuatan tarik komposit [11]. Namun ukuran partikel pengisi yang terlalu kecil juga mengakibatkan terjadinya penurunan nilai kekuatan tarik komposit, seperti pada ukuran 230 dan 260 mesh

Pada komposisi pengisi $40 \%$ dan $50 \%$, kekuatan tarik dari komposit epoksiPS/SKKD mengalami fluktuasi seiring dengan menurunnya ukuran partikel. Hal ini disebabkan oleh terjadinya aglomerasi dari pengisi serbuk kulit kerang darah. Aglomerasi dapat menurunkan kekuatan tarik yang terjadi apabila komposisi pengisi yang terlalu besar.

\section{Kekuatan Bentur (Impact Strength)}

Kekuatan bentur merupakan suatu parameter apakah suatu bahan bersifat kuat atau rapuh. Kekuatan bentur menunjukkan seberapa besar energi yang dihasilkan untuk menghancurkan bahan melalui hantaman pada suatu permukaan. Bahan yang kuat memiliki nilai kekuatan bentur yang tinggi sedangkan bahan yang rapuh memiliki nilai kekuatan bentur yang rendah.

Gambar 2 menunjukkan hasil sifat 
kekuatan bentur pada komposit epoksiPS/serbuk kulit kerang darah (SKKD).

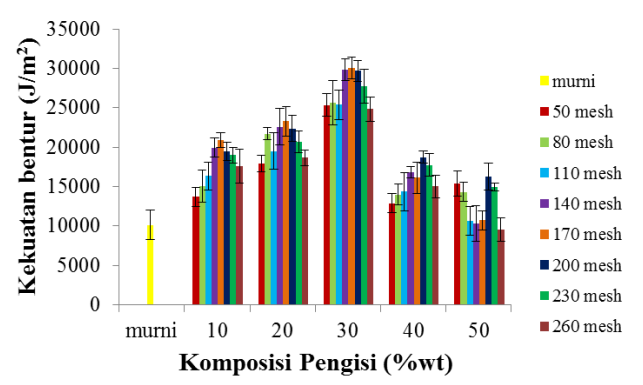

Gambar 2. Pengaruh Komposisi Dan Ukuran SKKD Terhadap Kekuatan Bentur Komposit Epoksi-PS/SKKD

Pada gambar 2 dapat dilihat bahwa dengan menambahkan pengisi serbuk kulit kerang darah, nilai kekuatan bentur komposit epoksi-PS/SKKD menjadi lebih tinggi dibandingkan dengan epoksi-PS murni tanpa penambahan serbuk kulit kerang darah. Kekuatan bentur komposit epoksi-PS/SKKD terus mengalami peningkatan seiring dengan penambahan serbuk kulit kerang darah sampai komposisi $30 \%$ yaitu sebesar 30044,3 J/m² pada ukuran 170 mesh.

Kulit kerang darah termasuk material yang keras dengan satu komponen dominannya adalah magnesium oksida $(\mathrm{MgO})$ yang sebelumnya telah digunakan oleh Deya'a dkk sebagai pengisi untuk meningkatkan kekuatan bentur dari komposit epoksi. Dari penelitian tersebut, dilaporkan bahwa magnesium oksida terbukti dapat meningkatkan nilai kekuatan bentur dari komposit epoksi. [9]. Hal ini mendukung hasil yang didapat, di mana penambahan serbuk kulit kerang darah dapat meningkatkan kekuatan dari komposit secara mekanik

Pada komposisi pengisi $40 \%$ dan 50\% terjadi penurunan drastis dari kekuatan bentur komposit epoksi-PS/SKKD hingga mencapai nilai $10615,0 \mathrm{~J} / \mathrm{m}^{2}$ pada komposisi $50 \%$ dengan ukuran 110 mesh. Penurunan yang terjadi disebabkan oleh aglomerasi pengisi serbuk kulit kerang darah.

Pada gambar 2, dapat dilihat juga pengaruh ukuran pengisi terhadap sifat kekuatan bentur dari komposit, dimana pada komposisi yang sama, nilai kekuatan bentur yang paling tinggi terdapat pada ukuran 170 mesh yaitu sebesar $30044,3 \mathrm{~J} / \mathrm{m}^{2}$, terkecuali untuk komposisi pengisi tinggi. Ukuran partikel yang lebih kecil, akan memberikan nilai kekuatan bentur yang lebih tinggi, asalkan tidak ada kecacatan sampel, dan tidak terjadi aglomerasi partikel pengisi [23].
Namun pada ukuran yang terlalu rendah seperti pada 200 mesh, nilai kekuatan bentur mengalami penurunan. Pada komposisi yang tinggi dan ukuran partikel yang terlalu kecil dapat mengakibatkan terjadinya aglomerasi yang dapat menurunkan nilai kekuatan bentur dari komposit.

\section{Kesimpulan}

Semakin meningkatnya komposisi pengisi SKKD pada komposit epoksi-PS/SKKD hingga mencapai $30 \%$ akan meningkatkan sifat kekuatan tarik dan kekuatan bentur dari komposit, sedangkan semakin kecil ukuran partikel dari pengisi SKKD pada komposit epoksi-PS/SKKD akan cenderung meningkatkan nilai kekuatan tarik dan kekuatan bentur dari komposit. Namun komposisi yang terlalu besar, dengan ukuran partikel kecil akan memicu terjadinya aglomerasi pengisi yang dapat menurunkan nilai kekuatan tarik dan kekuatan bentur dari komposit. Nilai kekuatan tarik mencapai nilai 5,50 MPa yang diperoleh pada komposisi 30\% dengan ukuran pengis 200 mesh sedangkan nilai kekuatan bentur komposit mencapai $30044,3 \mathrm{~J} / \mathrm{m}^{2}$ yang diperoleh pada komposisi $30 \%$ dengan ukuran partikel 170 mesh.

\section{Daftar Pustaka}

[1] Asy'ari, Hasim, Pengaruh Polutan Industri Terhadap Kinerja Mekanis Bahan Isolasi Resin Berpengisi Silicone Rubber dan Rice Husk Ash, Jurnal Penelitian Sains dan Teknologi, Vol 9, Nomor 1, hal 94-106, 2008.

[2] Bahrom, Radin Mohd Ali Bin Radin, Mechanical Property Evaluation of Bamboo Fiber Reinforced Epoxy Composite, Thesis, Faculty of Mechanical Engineering, Universiti Malaysia Pahang, 2009.

[3] Bray, D.J., Dittanet, P., Guild, F.J., Kinloch, A.J., Masania, K., Pearson, R.A., Taylor, A.C., The Modeling of The Toughnening of Epoxy Polymers via Silica Nanoparticles: The Effects of Volume Fraction and Particle Size, Elsevier Ltd Polymer, Vol.54, hal 70227032, 2013.

[4] Callister, W.D., Material Science and Engineering, Seventh Edition, John Wiley \& Sons, Inc., 2007.

[5] Campbell, F.C., Structural Composite Materials. ASM International. Hal 1, 2010. 
[6] Chanap, Rahul, Study of Mechanical and Flexural Properties of Coconut Shell Ash Reinforced Epoxy Composites, Thesis, Department of Mechanical Engineering, National Institute of Technology Rourkela, 2012.

[7] Chen, J., Kinloch, A.J., Sprenger, S., Taylor, A.C., The Mechanical Properties and Toughening Mechanisms of An Epoxy Polymer Modified with Polysiloxane-Based Core-Shell Particles, Elsevier Ltd Polymer, Vol.54, hal 42764289, 2013.

[8] Department of Defense Handbook. Composite Material Handbook, MILHDBK, 2002.

[9] Deya'a, B.M., Hussein, F.M., Dway, I.G., Studying the Impact Strength of Epoxy with $\mathrm{TiO}_{2}$ and $\mathrm{MgO}_{2}$ Composite, Eng and Tech Journal, Vol 29, No. 10, 2011.

[10]Faisal, Tengku, Z. H., Pengaruh Modifikasi Kimia Terhadap Sifat-Sifat Komposit Polietilena Densitas Rendah (LDPE) Terisi Tempurung Kelapa, Tesis Magister, Sekolah Pascasarjana, USU, Medan, 2008.

[11]Friedrich, K., Fakirov, S., Zhang, Z., Polymer Composite From Nano to Macroscale, Springer Science Business Media, Inc., 2005.

[12] Garcia, M.G., Marchese, J., Ochoa, N.A., Effect of the Particle Size and Particle Agglomeration On Composite Membrane Performance, Journal Of Applied Polymer Science, Vol. 118, 2010.

[13] Grisha, C., Sanjeevamurhty, Srinivas, G.R., Sisal/Coconut Coir Natural FibersEpoxy Composites: Water Absorption and Mechanical Properties. International, Journal of Engineering \& Innovative Technology, Vol 2, issue 3, 2012.

[14] Kaw, Autar K., Mechanics of Composite Materials, Second Edition, Taylor and Francis Group, 2006.

[15] Kusuma, E.W., Pemanfaatan Limbah Kulit Kerang Sebagai Bahan Campuran Pembuatan Paving Block. Skripsi, Teknik Lingkungan, Fakultas Teknis Sipil dan Perencanaan, Universitas Pembangunan Nasional Veteran Jatim Surabaya, 2012.
[16]Manoj, S. and Vikas, C., Mechanical Properties of Epoxy Resin-Fly Ash Composite, Journal of Minerals \& Materials Characterization \& Engineering., Vol. 9, No.3, Hal 199-210, 2010.

[17]Nadjib, M., Studi Pemanfaatan Kulit Kerang Sebagai Bahan Penyusun Pada Pembuatan Lem Kaca, Skripsi Jurusan Kimia, Institut Sepuluh November, 2008.

[18] Pamungkas, Adi, Studi Sifat Mekanik dengan Pengujian Tarik dan Ketangguhan Retak pada Komposit Epoksi-Kaolin, Metrik Polban, Vol 5, No.1, hal 1-5, 2011.

[19]Payae, Y., Lopattananori, N., Adhesion of Pineapple-Leaf Fiber to Epoxy Matrix: The Role of Surface Treatments. Songklanakarin, Journal of Science and Technology, Vol 31(2), hal 189-194, 2009.

[20] Priyadi, I., Rusnoto, L. Sifat Mekanis Komposit Resin Epoksi berpenguat Serbuk Kayu Sengon (Paraserianthes falcataria), Jurusan Teknik Mesin, Universitas Pancasaki Tegal, 2013.

[21]Siregar, Ika Gustiani, Studi Keanekaragaman Makrozoobentos Di Pantai Mutiara 88 Kabupaten Serdang Bedagai Sumatera Utara, Skripsi Jurusan Biologi, Fakultas Matematika dan Ilmu Pengetahuan Alam, Universitas Negeri Medan, 2012.

[22] Siregar, S.M., Pemanfaatan Kulit Kerang dan Resin Epoksi Terhadap Karakteristik Beton Polimer, Tesis, Magister Ilmu Fisika, Sekolah Pascasarjana Universitas Sumatera Utara, 2009.

[23]Soemardi, T.P., Kusumaningsih, W., Irawan, A.P., Karateristik Mekanik Komposit Lamina Serat Rami Epoksi Sebagai Bahan Alternatif Soket Prostesis, Makara Teknologi. Vol. 13, No.2, 2009.

[24] Yulianda, Mery, Pengaruh Perebusan Kerang Darah (Anadora granosa) Terhadap Penurunan Kadar Logam Kadmiun (Cd) Menggunakan Akuades dan Larutan Jeruk Nipis (Citrus aurantifolia Swingle) Secara Spektofotometri Serapan Atom, Skripsi Fakultas Farmasi, Universitas Sumatera Utara, 2010. 